\section{DIGITAL COMMONS \\ @ UNIVERSITY OF SOUTH FLORIDA}

\section{ABO: Interactive Journal for Women in the Arts, 1640-1830}

Volume 4

Issue 2 Volume 4.2 (Fall 2014)

Article 3

2014

\title{
Discomforting Narratives: Teaching Eighteenth-Century Women's Travelogues
}

Elizabeth Zold
Winona State University, ezold@winona.edu

Follow this and additional works at: https://digitalcommons.usf.edu/abo

Part of the Educational Methods Commons, Feminist, Gender, and Sexuality Studies Commons, and the Literature in English, British Isles Commons

\section{Recommended Citation}

Zold, Elizabeth (2014) "Discomforting Narratives: Teaching Eighteenth-Century Women's Travelogues," ABO: Interactive Journal for Women in the Arts, 1640-1830: Vol.4: Iss.2, Article 3.

http://dx.doi.org/10.5038/2157-7129.4.2.3

Available at: https://digitalcommons.usf.edu/abo/vol4/iss2/3

This Pedagogy is brought to you for free and open access by Digital Commons @ University of South Florida. It has been accepted for inclusion in ABO: Interactive Journal for Women in the Arts, 1640-1830 by an authorized administrator of Digital Commons @ University of South Florida. For more information, please contact digitalcommons@usf.edu. 


\title{
Discomforting Narratives: Teaching Eighteenth-Century Women's Travelogues
}

\author{
Abstract \\ In this essay, I describe an undergraduate course I designed and taught on eighteenth-century women's \\ travelogues and advocate for more courses that explicitly focus on noncanonical genres and authors. \\ Using student papers, I explore how students worked through their discomfort with new genre \\ conventions and improved their overall reading and analytical skills. I hope that my outline of the course \\ will be useful to those who teach or will be teaching women's travel literature or who wish to focus \\ courses on noncanonical authors and genres. \\ Keywords \\ travelogues, Lady Mary Wortley Montagu, Second Life, discomfort \\ Creative Commons License \\ (c) () $\ominus$
}

This work is licensed under a Creative Commons Attribution-No Derivative Works 3.0 License. 
At the end of each semester, I ask students to write advice for future students, which I publish on the last page of each new syllabus. After a semester of reading and navigating eighteenth-century women's travel narratives in my "Women's Literature in a Global Context" course, one student wrote, "Be very open to what you read and be willing to try to read something you might have never experienced before." Her advice paralleled that often given to travelers. In fact, many of her classmates also urged future students to keep an open mind about what they read in class. Having witnessed many of them struggling with travelogues over the course of 15 weeks, I was pleased that many overcame their initial discomfort with the genre and saw that the narratives were worth the struggle. But the road to get there was a long and at times uncomfortable one, not unlike the travels they read about in class. Indeed, the metaphor of students as travelers guided much of the semester.

Students had initially balked upon finding out that the women's literature course was comprised of only eighteenth-century women's travelogues. Of the twenty-six students in the course, the majority juniors and seniors, twenty were English or English Education majors; several had taken a course on eighteenth-century literature prior to taking this course, which counted as an elective fulfilling a general education requirement. Most had never heard of the travelogue as a genre. While travel literature courses have become increasingly recognized as valuable thanks in part to postcolonial and feminist studies, travel writing has nevertheless often "present[ed] a problem for academic studies" (Clark 2). As Clark explains, travel writing is too empirical to necessarily be considered in the canon of literature; the emphasis on empirical observation is especially true for most eighteenth-century travelogues. Certainly, some eighteenth-century travelogues have become incorporated into the canon, such as Lady Mary Wortley Montagu's Turkish Embassy Letters, although their fictional counterparts like Daniel Defoe's Robinson Crusoe have been much more widely read. Therefore, while a travelogue might find its way onto a syllabus, Clark rightly points out that the "force" of travel literature is "collective and incremental rather than singular and aesthetic" (1), so singling out one travel narrative does not do justice to this vast genre. In dedicating an entire semester to travel literature, specifically eighteenth-century travelogues written by women, I reinforced the collective nature of the genre, which goes hand in hand with its role in the gathering and construction of knowledge during the seventeenth and eighteenth centuries. For example, the dialogic and collective nature of travel literature became clear to students when they read Lady Elizabeth Craven's Journey through the Crimea to Constantinople (1789) and Montagu's Turkish Embassy Letters (1763) and compared them to short excerpts from travelogues by Paul Rycaut and Aaron Hill, who also visited Turkey. Each woman's travelogue about Turkey is situated within and responds to the large body of narratives about Turkish culture that, at varying points, contradict and reinforce each other. Women travelers and writers were a part of the public discourse that constructed knowledge about the world, which subverts most student expectations that women were relegated to domestic spaces. Moreover, prolonged exposure to an unfamiliar genre requires students to confront textual difficulties stemming from reading new narrative forms rather than ignoring them or simply disliking the one book of that genre they read for a course.

My goal was to use students' discomfort productively in the classroom, teaching them how to read and analyze a new genre, as well as introducing them to previously marginalized female authors. According to Michalinos Zembylas and Claire McGlynn, discomfort in the classroom can be productive because it challenges students' emotions, which in turn allows their viewpoints 
to change. Moreover, Zembylas and McGlynn argue, discomfort as a pedagogical tool is "inextricably linked" to the critical role emotions play in the disruption of "hegemonic perceptions and feelings" (43). In other words, discomfort may be necessary if a major purpose of teaching is to dislodge long-held student assumptions, worldviews, and emotions, a purpose for which travel literature is an especially conducive genre. As Denise Comer notes in her essay on privilege and teaching travel literature, the genre is "inherently and inextricably bound within rich contexts of geography, colonialism, imperialism, race, class, and gender, and as such . . . encourag[es] students to critically interrogate their own and others' positions in the world and the concomitant relationships therein" (71-72). Exploring larger social issues surrounding race, class, imperialism, and geography seemed especially important for my students given the rather homogenous makeup of the university, a large, public research institution; less than $20 \%$ of the undergraduate students identify as minority. Thus, much like the discomfort travel writers faced when encountering alterity abroad that pushed them to enlightenment about themselves as well as the world around them, students experiencing discomfort while reading this unfamiliar genre may also reach moments of enlightenment about their place in the world.

In addition, I wished to disrupt students' perceptions regarding the canon of literature and what constitutes literature and narrative form, especially within the context of eighteenth-century studies. By requiring students to continually work with travelogues in a multitude of ways throughout an entire semester, I encouraged them to work through their discomfort in order to become stronger readers and to change their view of eighteenth-century women's travelogues. ${ }^{1}$ While my focus is on travel literature, students would benefit from more courses centered on any number of unfamiliar genres and marginalized authors, with the time to experience and process the discomfort over the course of a semester.

\section{Eighteenth-Century women's travelogues}

The eighteenth-century travelogue was a genre dominated by male travelers and explorers who cataloged the lands and peoples they encountered. Medieval travel narratives like The Travels of Sir John Mandeville (ca. 1357) had roots in the encyclopedic form, a convention that continued into the eighteenth century. Eighteenth-century travelogues do not follow a traditional "story" narrative, like that found in fiction, as much as they provide readers with descriptions of local flora and fauna alongside a chronicle of interactions with people and culture. The narratives often describe what Mary Louise Pratt calls the "contact zone," the space where two groups of people who had been historically and geographically separate come together and establish a relationship, "usually involving conditions of coercion, radical inequality, and intractable conflict" (6). While there were fewer travelogues written and published by women, descriptions of the contact zone abound in their narratives, from Janet Schaw's descriptions of slaves in the West Indies - in which she sympathizes with the slave traders - to Anna Maria Falconbridge's depictions of African tribal leaders. What at first seem to be anecdotes of clashing cultures, uncertainty, and at times fear or danger reveal themselves as important moments of contact in which beliefs about native peoples are formed and cemented.

The element of danger inherent in the contact zone was one of the many reasons women were discouraged from traveling, which Mary Wollstonecraft acknowledges in her Letters Written during a Short Residence in Sweden, Norway, and Denmark (1796). Traveling with only her 
daughter and nursemaid, Wollstonecraft writes that upon arriving on shore, "I was not sorry to see a female figure, though I had not, like Marguerite [the nursemaid], been thinking of robberies, murders, or the other evil which instantly, as the sailors would have said, runs foul of a woman's imagination" (8). Dangers awaiting women on the road were not found just in women's imaginations, however. Kristi Siegel explores how medical rhetoric in the eighteenth century fostered the notion that women's bodily processes were "innately pathological" and "served to weaken women's clearly inferior bodies" (63). Thus, Siegel explains, eighteenthcentury culture dictated that women were to stay at home where they would be physically safe and protected. Instead, women were encouraged and recommended to read travelogues (Batten 28), a genre that periodicals such as the Critical Review argued provoked natural curiosity and "should be universally read" (Vol. 1, 309).

Women travelers, then, not only defied cultural norms, but by publishing travelogues they complicated the narrative male explorers and writers had constructed about cultures, peoples, and lands around the world. The explicit function of the eighteenth-century travelogue was to instruct readers through an interesting, truthful relation of observations and reflections. The truth of a travelogue — or the appearance of truth—was paramount, since the information it contained contributed to a growing knowledge about the world and its inhabitants (which of course had been filtered through a distinctively Western lens). Whether they were forging new paths or contradicting accounts of oft-traveled routes, women travel writers in the eighteenth century entered into the discourse of knowledge, though they were far fewer in number than their male counterparts. Thus, the reading list for my course was slightly constrained by accessibility to the texts, since students did not have access to databases like Eighteenth-Century Collections Online (ECCO) where out-of-print texts could be found. ${ }^{2}$ I included more well-known travelogues, such as Montagu's Turkish Embassy Letters (1763) and Wollstonecraft's Letters Written during a Short Residence in Sweden, Norway, and Denmark (1796), as well as lesser-read narratives such as Anna Maria Falconbridge's A Narrative of Two Voyages to the River Sierra Leone (1793) and Lady Elizabeth Craven's A Journey through the Crimea to Constantinople (1789). To get a range of texts from across the century, including those written but not published in the eighteenth century, like Maria Nugent's diary about her time in Jamaica, I also used Elizabeth Bohls's and Ian Duncan's excellent anthology, Travel Writing 1700-1830. ${ }^{3}$

As a way to help students enter the conversation about the genre, during the first week of class, I outlined some general characteristics and conventions of travelogues. In Pleasurable Instruction (1978), Charles Batten lays out the conventions of travel literature and their evolution throughout the eighteenth century. Travelers knew to talk about their experiences instead of themselves in order to avoid charges of egotism, to write in a plain style and avoid the ornaments of rhetoric, to make use of encyclopedic categorization of what they saw, and to write on the spot. Travelogue prose written according to such conventions gave the appearance of objectivity, which emphasized the supposed truthful nature of the genre and, by extension, the morality of the author. Consequently, the conventions and language within a woman's travelogue could help to reinforce her status as a moral woman, a critical reassurance because the conduct of women who traveled was of significant concern in the eighteenth century. Katherine Turner argues that the anxiety over women travelers was tied to the eighteenth-century middle-class morality placing women at the center of the domestic sphere. Conduct books identified "the absent woman" who abandoned her civic and domestic responsibilities as the source of potential "national calamity" 
(140). The moral dubiousness of women travelers seeped into other genres, like fiction, which Turner explains represented women who traveled as doing so out of suspicious circumstances or because of a compulsion (143). In discussing the moral implications of the conventions, students began to read the travelogues through a historically contextualized lens, realizing that women travel writers needed to work against these tropes.

The heavy risk for women travelers who published their narratives in the eighteenth century explains in part why there were so few who chose to do so and highlights the significance of their contributions. Somewhat paradoxically, their scarcity underscored their novelty, a trait prized by travelogue readers. For example, Montagu was the first Englishwoman to publish about Turkey; her letters helped shape popular conceptions about Turkish women, culture, and literature. ${ }^{4}$ Anna Maria Falconbridge published the first account of Africa by an Englishwoman, and her narrative is one of the few existing documenting the founding of the colony that would become Sierra Leone's capital. But their narratives did more than provide information about foreign lands: travel provided an opportunity for a social critique as well. Montagu argued that the veil Turkish women wore was sexually liberating and lamented the lack of such freedom for her fellow countrywomen, while Falconbridge used her narrative to mount a public case against powerful leaders of the abolitionist movement who owed her money and whose mishandling of funds caused the colony to suffer. Compelling and often daring writers, women travelers dared to place their narratives in the public sphere despite the potential threat to their reputations.

As a way of contextualizing the contemporary reception of eighteenth-century women's published travelogues, I brought in critical reviews of several of the books from eighteenthcentury periodicals. The May 1763 issue of the Monthly Review featured a review of the first edition of Montagu's letters, with the review noting several grammatical errors but praising the letters for their plain style: "There is no affectation of female delicatesse, there are no prettynesses, no Ladyisms in these natural, easy familiar Epistles" (Vol. 28, 385). Students noticed that the response is clearly gendered, a bias that appears in reviews of Craven's travel narrative as well. The March 1789 issue of the English Review begins the review of her travelogue with a commentary on women writers: "The efforts of female writers we always consider with a mixture of pleasure and concern; . . . we feel sorry for the necessity our duty too frequently imposes upon us of damping their ardour of composition by exposing its errors and defects. This duty, however, it is our object to discharge . . a as guardians of the moralities of literature" (Vol. 8, 161). The review continues on to list what the critics view as the "flaws" of Craven's writing. Clearly reading women's texts differently than men's, the critics admit their concern over the frequency with which they must point out language errors in women's writing. Such overt emphasis by the critics on seeing themselves as moral guardians by policing language use illuminated for students the ties between language and morality, which underscored the imperative to utilize conventions like writing in plain language given the precarious moral situation in which women travel writers found themselves.

\section{Trouble with genre}

The travelogue was a dominant form of literature in the eighteenth century, but, unsurprisingly given the historical distance, none of my students had even heard of it and were therefore unfamiliar with its form. During the construction of the course, I had originally assumed that the 
majority of the discomfort would come from discussing topics stemming from the travelogues: how eighteenth-century women travelers presented African people, described bodies of the Other, and made assumptions about members of lower classes, among similar issues that develop in the contact zone. When we addressed these issues, I found that many students used the historical distance as a buffer from the discomfort, which itself was problematic and required attention. Their attitude was that since these texts were written so long ago, their descriptions and stereotypes were products of a more "unenlightened" time that "we" (American society) had moved beyond. While they understood that these texts appeared truthful in the eighteenth century, students were quick to point out the obvious biases of the authors. ${ }^{5}$ I also found that students focused on their discomfort with the form of the texts. As I learned through class conversations early on in the semester, learning how to read was just as or more important to them than what they were reading. As one student wrote upon looking back over the semester, "For me, knowing how to read these texts was the only way to get through the class."

Many students had no idea how even to approach reading the genre. Like travelers encountering foreign cultural practices, students tried to reconcile this unfamiliar genre with what they were most comfortable. One student reflected at the end of the semester, "When I first enrolled in the class, I didn't quite know what to expect, so for the first travelogue I focused on things found in more 'traditional' readings (traditional in that I was more used to these methods) such as themes, character development, symbols and so forth." For this student and others, focusing on characteristics often discussed in fiction writing would not prove successful. Students confessed they were most comfortable reading novels - and fiction in general-because they were familiar with the structure and had been taught how to follow a traditional plot. For many, the reading problems were stratified: not knowing what to expect led to confusion about the narrative form, which created discomfort with the reading material that seemed like endless meaningless descriptions of people and nature. As one student wrote in an end-of-the-semester reflection,

Toward the beginning of the semester, I had no idea what to look for in a travelogue. I simply read it like any other book, waiting for a major plotline or major characters to help me understand what was going on. That worked fairly well with Oroonoko, as his story was essentially the travelogue. As time went on, however, I learned that it is important when reading travelogues to look for themes rather than plotlines.

Students often wanted to apply their prior knowledge of reading novels to how they read travelogues, which at the beginning of the semester resulted in a dislike of the genre.

Students' initial reactions to travelogues are not wholly unexpected and reveal the importance of immersing them in an unfamiliar genre. As Steen F. Larsen and János László found in their study of the appreciation of literature, differences in "conventional narrative structures" between cultures influence comprehension and impede the "personal resonance" that readers seek in reading literature (426 and 427); as a result, this lack of personal resonance affects readers' appreciation of the literature (438). Eighteenth-century England can be marked reasonably as a different culture, and the narrative form of the travelogue has a much different purpose and structure than novels. As one student wrote early on in the semester, a travelogue's "vivid, longwinded descriptions of everything seen and everywhere the author travels is a barrier to the 
modern reader. We have been conditioned to expect certain things out of a story, and I don't think travel narratives fit our preconceived notions." The student goes on to write that the long diversions in travelogues are particularly difficult because he expects "good" stories to be entertaining, which he did not find these to be. The expectation, at least for this student, of what literature is (a story) and what confronted him in eighteenth-century travelogues (nonlinear sets of descriptions and events) made it difficult for him to engage with or appreciate the text.

In a study on student understanding of different types of texts from different literary genres, Susan Hallam and Hazel Francis (1998) report that readers attributed complications of understanding to the genre or style of the texts even when they had adequate prior knowledge of the topic (94). In this case, of course, most students were reading travelogues without any prior knowledge of what to expect from the narrative. Furthermore, Francis and Hallam (2000) demonstrate how learning in higher education is affected by students' ability to react to and deal with different genres. Francis and Hallam found that students reported anxiety over the difficulty of certain genres and that much of their difficulty understanding a text was tied specifically to genre-specific conventions like language and narrative structure. Moreover, they found that readers felt "threatened by their difficulties" with reading and understanding (293). A student in my course confessed, "I did not feel confident after reading the texts. Some of the time, after reading a few pages, I would stop and think about what I just read, and I realized that I did not comprehend most of it." As Francis and Hallam found, when confronted with a new genre, students may often dismiss or avoid it because it presents them with difficulties or anxiety.

In my course, students who felt strong discomfort about not understanding a genre often cited the necessity to read and reread as a source of frustration, especially for students who, as future English teachers, considered themselves to be strong readers. As one student admitted in a reflection paper,

When I first began to read travelogues, I quickly became frustrated. I was frustrated because the text itself was very difficult to read and comprehend. The texts were many times the original writings and styles of the time period that they were written. This made the reading very difficult . . . I found myself going back and reading the sentence I had just read two and sometimes even three times.

Another echoed that sentiment, describing what it was like for her to read travel literature: "From the minute I started to read the first line, I knew I was going to have difficulty ... I was not able to read this text as naturally as I was used to. I had to concentrate on each word and even reread each sentence just to comprehend what I had just read. Once again, this was not something I was used to as a reader." Students had to devote a significant amount of time to reading the genre in order to process this new form. Indeed, by working through these frustrations, students saw themselves change as readers over the course of the semester, even students who came to the class confident in their reading abilities. One student, an English major, wrote, "The very first text we read, Oroonoko, was incredibly difficult for me to read, even though I thought I had a rich reading background. After the reading of travelogues we did in this course, I definitely think my identity as a reader has been enhanced." 


\section{Teaching strategies}

As might be expected, the biggest challenge was increasing students' literacy in eighteenthcentury travel narratives, followed closely by dismantling notions that cultural and racial biases in travel literature were confined to the past. In order to facilitate student success in both areas, I scaffolded each element of their coursework, concentrating on how to read the genre and discussing its continued impact on history and culture. For example, the main reading strategy I emphasized involved breaking apart each narrative to find patterns of images and topics, such as bodily descriptions or how flora and fauna were depicted, rather than trying to find a (nonexistent) single plot thread throughout a narrative. Throughout the semester, I emphasized these details as important for analyzing a text's larger cultural importance: that is, what does each narrative tell us about the culture in which it was produced, how does it portray the nations and cultures encountered, and how does it portray the author and itself within eighteenth-century guidelines and purposes of the travelogue genre? Furthermore, what remnants of these travelers' "knowledge" about other peoples and cultures remain today? What follows are descriptions of class activities and assignments meant not just to shape students into stronger readers but to emphasize why women's travel narratives were so important within the eighteenth century's historical and cultural context.

\section{In-class jigsaw activities}

Many in-class activities, especially early in the semester, centered on modeling for students the strategies for reading travel literature. Perhaps the most successful was a jigsaw activity using small groups and close reading to bolster confidence in reading and understanding travelogues. The jigsaw activity asks students first to look closely at a text to find patterns and analyze their importance; then students are required to explain how those patterns contribute to the reader's understanding of the text as a whole. The activity was meant to reframe the students' approach to travel literature. Rather than having them look for a linear plot, I wanted to focus their thinking on larger themes and topics that occur throughout many eighteenth-century travelogues because travelogues, like fiction with its plot structure, have a set of reoccurring and defining characteristics. Beginning with the micro perspective and then moving to the macro is something many students, especially English majors, are used to doing when analyzing fiction-with, say, the use of a symbol within a short story-but need to have reframed to fit the travelogue genre.

For example, while reading Lady Elizabeth Craven's Journey, students were put into groups of three or four and became "experts" on a topic they were assigned. I chose subjects like "descriptions of the Other," "women," "colonial ideology," or "gaze" (concepts we had discussed in class) that would be broad enough to let them choose their own angle but specific enough that they could find related passages in the narrative. I gave the groups roughly 20 minutes of a 75-minute class to find and analyze passages in the text that related to their topic, essentially performing a close reading as a group. Each of the group members took notes on what they discussed. For the second half of the lesson, one student from each of the groups came together to form a second group. In the second group discussion, each student shared what he or she discovered about the specific topic so every student in the class had all the notes. The goal of the second group was twofold: to share the findings about their individual topics and then to try to answer the question, "So what?" That is, what did analyzing these topics together do for their 
understanding of Craven's travelogue? Were there any patterns that emerged in her discussion of peoples and places? Several students noted during class that this activity was helpful in forming new strategies and approaches to reading travelogues.

\section{Writing analyses of the genre}

Over the course of the semester, students wrote four reading reflections in which they analyzed a specific component of a travelogue. They could either answer one of the questions I posed or address a topic in which they were interested; topics ranged from an author's use of travelogue conventions to an analysis of an author's gaze and subjectivity and how it affected the travelogue. The shorter analyses prepared them to write a longer analytical paper as a final project for the course. Thus, students had to consistently engage with the texts on an analytical level throughout the semester. This sustained level of close interaction with the travelogues was repeatedly mentioned on the end-of-semester survey as one of the most useful learning tools in the class. One student wrote that the reading reflections played a large role in enabling her to "analyze a travelogue and look at the techniques used and how they affected the [text]," while another cited them as the space in which she was able to put all of her thoughts together as the semester went along. Several students noted while handing in their final papers that they would not have believed in their ability to write such an in-depth analysis paper on a travelogue at the beginning of the semester.

\section{Second Life project}

In addition to analyzing the genre, students became immersed in it by actually writing a travelogue. While I used the online, immersive virtual platform Second Life as the place for them to explore, it is certainly not the only way to write a travelogue (especially if the classroom technology is not available). ${ }^{6}$ That said, Second Life has many pedagogical possibilities: it is an online community where users create avatars that serve as representations of themselves and literally work to build a virtual world where they can socialize with others. The Second Life space allows students to interrogate how they represent other communities within their own travel narrative. Within Second Life are "islands" that can be based on a real-life place like London or Africa; some universities even have virtual campuses. Visiting a variety of islands in a short time is easy, since the transportation options within the world include flying and teleporting. Users can go shopping for virtual clothes or accessories (including hair and skin) and buy or rent virtual land and homes. New users can find hubs where people from around the world gather to talk and connect. ${ }^{7}$

The assignment required students first to compose their own travelogue and then to reflect upon the experience. The world of Second Life is disorienting for most students, even those who play computer role-playing games like World of Warcraft. Many used their travelogue to work through feelings of alienation as well as frustrations about the mechanics and logistics of travel within the world. ${ }^{8}$ I was purposely flexible about how students could write their travelogue, giving very few specific guidelines regarding form or content. Students could choose to follow eighteenth-century conventions or flout them. Either way, textual choices needed to be explained and analyzed in the accompanying reflection paper. The Second Life project was purposefully placed in the middle of the semester, when students would have a basic understanding of the 
genre and would subsequently be able to apply their Second Life experiences to the second half of the course. Despite protestations that Second Life was creepy and full of strange "losers," or perhaps because of it, the Second Life project was a pivotal assignment for several students. As one student reflected,

This sounds bad, but without any previous knowledge of travelogues, or much experience reading so many texts that needed to be analyzed and read in a different way, I did not have very valuable things to say about the texts. A big turning point for me was writing my own travelogue. Analyzing why I made the textual choices I did gave me a connection with the authors of travelogues we were reading for the class. When I read travelogues from then on, I suddenly could better understand where the author was coming from.

Whether it was because they felt some of the alterity that Montagu or Falconbridge felt while abroad, or they simply realized how much effort it took to compose a travelogue, students finished the project with a new outlook on the genre.

The fact that students could effectively explore a new space but still remain physically safe was the main reason I chose Second Life for this project, although students certainly had to negotiate a new world and its potential discomforts. As both male and female students noted, they encountered some Second Life users who spoke to them inappropriately or approached them in ways that made them uncomfortable. Luckily, the students were able to fly or teleport out of these situations, and several students pointed out that these uncomfortable experiences often happen in real life as well. Nevertheless, these interactions with Second Life users were great fodder for the students' narratives. Much like women travelers whose opinions about a country or people were built upon contact with a few, students drew their readers a picture of Second Life as a community based on roughly five hours of visiting widely disparate subcommunities within the larger virtual space.

\section{The Couple in the Cage viewing}

Whereas students accept — and expect—fiction as what one reads in literature classes, I had to do more work to justify why an entire semester was spent on a genre they had never even heard of. In addition, feeling historically removed from these women's experiences and striving to distance themselves from the imperialist and racist descriptions in several of the texts, students had difficulty connecting with the authors or remaining invested in the narratives. Furthermore, they skirted their discomfort in discussions of race by dismissing the descriptions in the texts as historical ignorance and prejudice. Students needed to see the larger cultural impact that these texts had on the eighteenth century as well as the reverberations felt today, so I showed them the documentary The Couple in the Cage (1993) to demonstrate some of the large, long-term cultural impacts that texts like travelogues had on race relations and cultural understanding.

The Couple in the Cage is a documentary starring performance artists Coco Fusco and Guillermo Gómez-Peña, who put themselves on exhibit in a cage as "Amerindians" as a satirical commentary on how the West had constructed the savage, exotic Other. However, what Fusco and Gómez-Peña found was that the audience believed the exhibit to be real; as Fusco writes in 
her essay, "The Other History of Intercultural Performance," she and Gómez-Peña "underestimated public faith in museums as bastions of truth and institutional investment in that role" (154). From the Field Museum in Chicago to exhibits in Madrid and Mexico City, Fusco and Gómez-Peña had strangers paying to get their picture taken with them, to hear a story in their "native" Guantinaui tongue (a made-up language), or even to see Gómez-Peña's genitals. Clips from the exhibit are interspersed with accounts of the historical practice of displaying the bodies of indigenous people from around the world, including Saartjie Baartman, who was called "The Hottentot Venus," and Native Americans in Wild Bill's Wild West show.

The eighteenth-century attitudes toward indigenous peoples students had complained about were on full display for them in a twentieth-century context and within a building they all knew as one of progress and learning. (The university is a mere two hours from Chicago, which meant that many of the students were from the Chicago area and had visited the Field Museum before). Several students even equated the museums' ethos as institutions of learning to the eighteenthcentury belief in the objectivity of the travelogue and authority of the author. After the viewing, which garnered uncomfortable snickers and chair fidgeting, a few students offered that they would have been among those who were outraged by the piece if they had seen it and believed it were real. At first, the distance provided by the video echoed the historical distance they felt from the travelogues. However, a rich conversation ensued in which the class contemplated their role as viewers removed from the situation, thus complicating how they understood their own gaze. The conversation grew more complex when several students shared moments in their lives when they believed society placed them into metaphorical cages; one student described how she, a racial minority on a predominately white campus, at various points had been asked whether she was an international student or whether she spoke English, simply because of her skin color.

To use their discomfort to even more productive ends, I encouraged students to contextualize their reactions with what they had been reading so far in the semester. Students surmised that when a genre with an ethos for building knowledge presented people from parts of the world as Other and worthy of display, it contributed to the objectification and dehumanization of entire races and peoples. Recalling specific moments in the travelogues, such as Montagu's implication that African peoples were primitive because their ancestors mated with apes, students now understood the significance of these descriptions within a larger historical and cultural context. Viewing evidence of the long-term effects that the travelogue genre had on culture and racial understanding gave them a new tool with which to consider these narratives. Rather than viewing travelogues as filled with simple anecdotes or encyclopedic information, students now viewed the narratives as documents that, at the time, were considered to construct knowledge about the world. As a result, travelogues shaped and reinforced racial stereotypes that students recognized still affect our contemporary culture.

\section{Reflection and revision}

Of course, not all strategies were successful. To introduce students to the genre slowly, I assigned Aphra Behn's Oroonoko (1688), which is a blend of genres, including the novel and the travelogue. Thus, while students could follow a more traditional plot, they could also see the travelogue elements, such as the narrator's insistence on the truth as evidenced by her eyewitness testimony and her elaborate descriptions of the flora and fauna. As it turned out, assigning 
Oroonoko first actually seemed to work against my goals. Students' familiarity with the fictional narrative format allowed them to ignore most of the discomfort they had with the travelogue elements of the book. As one student explained while reflecting upon the course as a whole,

Unlike other works we have read throughout the semester, Oroonoko is written in a traditional narrative format. It was because of these factors that I found myself analyzing the story of Oroonoko as just that, a story, instead of a travelogue. Because it was written in a narrative format, it followed the Aristotelian plot model. It had a conflict, rising action, climax, falling action, and conclusion. Because I have been taught in so many literature classes to find these stages, I only focused on what was happening to the characters of Oroonoko and Imoinda. I did not focus on the techniques the author used, nor did I even focus on the aspect of travel in the narrative and what those things did for the story and the audience.

Another student recommended I drop Oroonoko from the reading list in the future, since her classmates "got too hung up on the fiction of it" because they "liked how familiar and defined it was."

Even with these setbacks, students were immersed in the travelogue genre the entire semester and learned to analyze it in as sophisticated a fashion as they do fiction. In courses where I have assigned one travelogue amid novels, poems, and plays, students simply complained about how difficult the reading was and very happily moved on to a genre with which they were more comfortable. They left the course with a negative opinion about travelogues-often citing the travelogue as the book I should consider removing from the syllabus-without ever needing to understand the genre. By requiring students to read, discuss, and analyze travelogues for an entire semester, they confronted and worked through their discomfort. Of course, I understand curricular constraints may not allow for dedicating an entire course to a noncanonical genre. For instructors with restrictions, I think even a truncated but sustained unit devoted to a noncanonical genre would serve to push students to confront discomfort when reading unfamiliar texts. Admittedly, at the start of the semester, I second-guessed my decision to devote what might have been students' only women's literature course to such a specific genre and time period. However, the students' growth as readers, the sophisticated theses and analyses in their final papers, and the broad range of social issues discussed in class alleviated any concern.

By the end of the semester, students overwhelmingly viewed travelogues as literature, a categorization that a few admitted was not the case at the beginning. As one student wrote in her final paper, "Reading the numerous travelogues this semester has given me a whole new perspective on the way I view them. What I presumed at first to not be literature but rather just history texts has completely changed." Echoing the new perspective on travelogues at the end of the course, one of her classmates noted, "[Now] I really do think they're valuable pieces of literature." One student, an English Education major, noted that he wanted to teach at least some of Wollstonecraft's letters alongside Mary Shelley's Frankenstein to enrich the experience of reading Shelley's prose. Clearly this course expanded their views of literature and highlighted the important historical and cultural work of travel literature. 


\section{Conclusion}

Classes structured around noncanonical genres allow for previously marginalized voices to be taught in the university classroom and complicate understandings of history and culture by exploring the long-lasting historical and cultural impact of these voices. Furthermore, noncanonical genres and authors often broaden students' views of what constitutes literature and strengthen their reading and analytic skills. As one student noted, reflecting on her growth as a reader over the course of the semester, "As the weeks went on, I began to feel comfortable reading them and analyzing [travelogues], too, but the way I approached the texts continued to evolve throughout the course of the semester." Much like travelers experiencing the unfamiliar, students encountering new genres will learn how to negotiate their feelings of alterity if they are provided time for reflection and growth.

\section{Women's Literature in a Global Context Syllabus}

\section{Required Texts:}

Oronooko (1688) by Aphra Behn

Turkish Embassy Letters (1763) by Lady Mary Wortley Montagu

A Journey through Crimea and Constantinople (1789) by Elizabeth Craven (Google books)

Narrative of Two Voyages to the River Sierra Leone (1794) by Anna Marie Falconbridge

Letters Written during a Short Residence in Sweden, Norway and Denmark (1796) by Mary Wollstonecraft

Travel Writing 1700-1830: An Anthology eds., Elizabeth Bohls and Ian Duncan

(Readings from the anthology include: Janet Schaw, Maria Nugent, Helen Maria Williams, Ann Radcliffe, Celia Fiennes, Dorothy Wordsworth, Mary Prince)

\section{Course Description:}

Travel narratives were extremely popular during the seventeenth and eighteenth centuries. While travelogues often boasted objectivity and "truth," they were subjective texts whose reception was often influenced by a variety of factors, including the gender and class of the author. Rooted in the Lockean philosophical belief that knowing was gained through experiences, travel narratives - even some that were later realized to be fiction-were seen as a collection of facts and truths; thus, these narratives constructed knowledge about the rest of the world.

In this course, we are going to be looking specifically at travel narratives written by women during the seventeenth and eighteenth centuries, beginning with Aphra Behn's Oronooko. We will investigate the various elements of travelogues, examining how they are written, and analyze the ways in which gender, class, and race play a role in their construction, both in the texts themselves and in the literary marketplace. To give more of a context for the construction of a travel narrative, you will be writing a travel narrative of your own that records your time exploring Second Life, a virtual, 3D world.

\section{Learning Outcomes:}

The learning outcomes for this course are that at the end of the semester, you will know/be able to: 
1. demonstrate a knowledge and understanding of seventeenth- and eighteenth-century travel narratives;

2. analyze how the elements of a travel narrative work to construct a specific imagining of culture, people, and places;

3. evaluate how the travel narratives construct gender and the rhetorical ways gender plays a role in the construction of the text;

4. discuss and explain the role of travel narratives within eighteenth-century literary culture;

5. interrogate the ways in which travel narratives are constructed, such as what is included and excluded.

\section{Notes}

${ }^{1}$ In order to trace students' progress throughout the semester, I used a variety of tools to gather data: homework, anonymous in-class surveys, and extensive notes from in-class discussions.

${ }^{2}$ Craven's text is no longer in print, so students read the first edition on Google Books.

${ }^{3}$ Please see the attached syllabus for a complete reading list for the course.

${ }^{4}$ Montagu, as an upper-class woman, found publishing to be vulgar. During her lifetime several manuscripts of her letters circulated. As Isobel Grundy notes, Montagu "belonged ... to an older world which published without printing" (200). Furthermore, it is clear that she edited her letters extensively and gave them to Rev. Benjamin Sowden in Rotterdam for publication; they were published shortly after her death in 1763 .

${ }^{5}$ That students did not take these narratives at face value was one of the few advantages of teaching older travelogues. As Valerie Smith explores in her essay on teaching contemporary travel writing, students can see nonfiction texts as holding cultural authority, making them less likely to approach such texts critically (54-55). The historical distance that eighteenth-century travelogues provide allowed students to see beyond what was purported to be true.

${ }^{6}$ This is not to say that Second Life is the only virtual world that would be useful in the classroom. While I have worked only with Second Life, there are a number of free virtual worlds available, including Twinity and InWorldz. Furthermore, the creators of Second Life, Linden Labs, confirmed in June 2014 that they were working on a new virtual world—without releasing details or specifics - which has led some to question the future of Second Life.

${ }^{7}$ Please see the accompanying video I made in Second Life for more specifics about the online virtual community. Regardless of which virtual platform is used, many of the same pedagogical applications apply.

${ }^{8}$ To my surprise, the students who identified as "gamers" disliked Second Life the most, citing its lack of objectives as its biggest weakness. One labeled it as simply a glorified chat room. 


\section{Works Cited}

Batten, Charles L., Jr. Pleasurable Instruction: Form and Convention in Eighteenth-Century Travel Literature. Berkeley, CA: U of California P, 1978. Print.

Clark, Steve, ed. Travel Writing and Empire: Postcolonial Theory in Transit. Intro. 1999. New York: Zed. Print.

Comer, Denise. "Negotiating Privilege in the Teaching of Travel Literature." Methods for Teaching Travel Literature and Writing: Exploring the World and Self. Ed. Eileen Groom. 2005. New York: Lang, 71-88. Print.

Critical Review. 1756. Vol. 1. London. Print.

English Review. 1789. Vol. 8. London. Print.

Francis, Hazel, and Susan Hallam. "Genre Effects on Higher Education Students' Text Reading for Understanding." Higher Education, 2000, 39.3: 279-96. Print.

Fusco, Coco. "The Other History of Intercultural Performance.” TDR 38.1 (1994): 143-67. JSTOR. Web. 25 Sept. 2014.

Grundy, Isobel. Lady Mary Wortley Montague. Oxford: Oxford UP, 1999. Print.

Hallam, Susan, and Hazel Francis. "Is My Understanding Yours? A Study of Higher Education Students' Reading for Understanding and the Effects of Different Texts." Learning and Instruction 8.1(1998): 83-95. Print.

Larsen, Steen F., and János László. "Cultural-Historical Knowledge and Personal Experience in Appreciation of Literature." European Journal of Social Psychology 20.5 (1990): 425-40. Print.

Monthly Review. 1763. Vol. 28. London. Print.

Pratt, Mary Louise. Imperial Eyes: Travel Writing and Transculturation. New York: Routledge, 1992. Print.

Siegel, Kristi. Gender, Genre, and Identity in Women's Travel Writing. New York: Lang, 2004. Print.

Smith, Valerie M. "Interrogating Houghton Mifflin's Best American Travel Writing Series." Methods for Teaching Travel Literature and Writing: Exploring the World and Self. Ed. Eileen Groom. New York: Lang, 2005. 71-88. Print. 
Turner, Katherine. British Travel Writers in Europe 1750-1800: Authorship, Gender, and National Identity. Burlington, VT: Ashgate, 2001. Print.

Wollstonecraft, Mary. Letters Written during a Short Residence in Sweden, Norway, and Denmark. 1796. Oxford: Oxford UP, 2009. Print.

Zembylas, Michalinos, and Claire McGlynn. "Discomforting Pedagogies: Emotional Tensions, Ethical Dilemmas and Transformative Possibilities." British Educational Research Journal 38.1 (2012): 41-59. Print. 